\title{
Clinical pharmacology of netilmicin in the newborn
}

\author{
A M R PHILLIPS AND R D G MILNER \\ Department of Paediatrics, University of Sheffield
}

SUMMARY The plasma peak, trough, and peak-trough concentrations of netilmicin given to preterm and term infants were measured after different regimens to determine which dosage would provide satisfactory peak and trough concentrations. In infants aged less than 7 days, dosage regimens of 3.0 or $2.5 \mathrm{mg} / \mathrm{kg}$ every 12 hours gave satisfactory peak levels (range $5.2-12.0 \mu \mathrm{g} / \mathrm{ml}$ ) but troughs were above the desirable maximum level of $3 \mu \mathrm{g} / \mathrm{ml}$ in more than half the preterm infants. Subsequently a dosage regimen of $3.0 \mathrm{mg} / \mathrm{kg}$ immediately followed by $2.0 \mathrm{mg} / \mathrm{kg}$ every 12 hours resulted in trough levels that exceeded $3 \mu \mathrm{g} / \mathrm{ml}$ in only 2 of 25 preterm determinations and never in term infants, yet gave satisfactory peak levels (range $4.5-7.4 \mu \mathrm{g} / \mathrm{ml}$ ). In preterm infants aged 4 to 7 weeks a dosage of $3 \mathrm{mg} / \mathrm{kg}$ every 8 hours gave satisfactory peak and trough levels.

Netilmicin is a recent addition to the aminoglycoside range of antibiotics which is claimed to be less nephrotoxic and ototoxic than gentamicin, ${ }^{12}$ is well tolerated clinically, ${ }^{3-8}$ and is effective against several gentamicin resistant strains of bacteria. ${ }^{9}$ In view of the potential value of the drug in the treatment of newborn infants this study was undertaken to determine which dosage regimens would provide satisfactory peak and trough concentrations of netilmicin in preterm and term infants. The manufacturers recommend the clinician to aim for a peak concentration of less than $12 \mu \mathrm{g} / \mathrm{ml}$ and a trough concentration of less than $3 \mu \mathrm{g} / \mathrm{ml}$.

\section{Patients and methods}

The infants studied were those admitted to the Regional Neonatal Intensive Care Unit, Jessop Hospital for Women, Sheffield from September 1981 to March 1982 who required broad spectrum antibiotic therapy for confirmed or suspected infection. At the time the trial began, the policy at the unit advocated the use of a combination of penicillin $G$ and gentamicin and the only change in clinical management was the substitution of netilmicin for gentamicin. Measurements were made on 80 babies, 48 of whom were preterm ( $<37$ weeks' gestation). Netilmicin (paediatric preparation 10 $\mathrm{mg} / \mathrm{ml}$, Kirby-Warrick Pharmaceuticals Ltd) was given by slow injection over 3 minutes into a peripheral vein.

The dosage in use on the unit for gentamicin was an immediate dose of $3 \mathrm{mg} / \mathrm{kg}$ with $2 \mathrm{mg} / \mathrm{kg}$ subsequent doses 12 hourly for neonates $<7$ days of age and 8 hourly for $>7$ days of age. However, the initial regimen for netilmicin was recommended as
$3 \mathrm{mg} / \mathrm{kg}$ every 12 hours but in the light of plasma netilmicin results the following regimens were also studied: $2.5 \mathrm{mg} / \mathrm{kg}$ every 12 hours, $3 \mathrm{mg} / \mathrm{kg}$ immediately followed by $2 \mathrm{mg} / \mathrm{kg}$ every 12 hours, and in infants aged 4 weeks or more, $3 \mathrm{mg} / \mathrm{kg}$ every 8 hours. Blood (100-150 $\mu$ l) was collected by heel prick into EDTA microtubes after at least four doses of netilmicin had been given to monitor plasma peak and trough levels. Specimens for trough levels were collected immediately before a netilmicin injection, and those for peak levels 30 minutes after the intravenous injection. Blood levels were monitored every 3 days to ensure against excessive serum levels and at the same time making sure the levels were therapeutically adequate. To attain the optimum regimen with these requirements the dose of netilmicin was decreased if the peak level exceeded $12 \mu \mathrm{g} / \mathrm{ml}$ or the trough level exceeded $3 \mu \mathrm{g} / \mathrm{ml}$. All blood samples were centrifuged immediately after collection and most were analysed the same day or no later than the next day. Netilmicin was measured by an enzyme immunoassay (Syva) which used $50 \mu l$ of plasma and has an intra-assay coefficient of variation of $<10 \%$ over the range $2-10 \mu \mathrm{g} / \mathrm{ml}$ and an interassay coefficient of variation of $<15 \%$. In 16 infants who received gentamicin therapy, gentamicin blood levels were measured according to the same protocol as that used for netilmicin.

Comparisons between the mean peak, trough, or peak-trough differences of different groups of infants were made using Student's $t$ test.

\section{Results}

Twenty four preterm and 16 term infants were given at least four doses of $3 \mathrm{mg}$ netilmicin/kg every 12 
Table 1 Mean $\pm S D$ plasma netilmicin levels $(\mu \mathrm{g} / \mathrm{ml})$ in preterm and term infants aged less than 7 days

\begin{tabular}{llll}
\hline Dosage & Peak & Trough & Peak-trough \\
\hline Preterm & & & \\
$3.0 \mathrm{mg} / \mathrm{kg} \times 12 \mathrm{~h}$ & $8 \cdot 3 \pm 1.7(34)$ & $3.5 \pm 0.8(36)$ & $4 \cdot 8 \pm 0.9(33)$ \\
$2.5 \mathrm{mg} / \mathrm{kg} \times 12 \mathrm{~h}$ & $7.7 \pm 1.2(13)$ & $2 \cdot 9 \pm 0.7(13)$ & $4.7 \pm 0.9(13)$ \\
$2.0 \mathrm{mg} / \mathrm{kg} \times 12 \mathrm{~h}$ & $5.7 \pm 0.7(18)$ & $2 \cdot 2 \pm 0.6(25)$ & $3.4 \pm 0.4(18)$ \\
Term & & & \\
$3.0 \mathrm{mg} / \mathrm{kg} \times 12 \mathrm{~h}$ & $7.0 \pm 1.3(24)^{*}$ & $2.5 \pm 0.7(25)^{*}$ & $4.4 \pm 0.9(23)$ \\
$2.0 \mathrm{mg} / \mathrm{kg} \times 12 \mathrm{~h}$ & $5.3 \pm 0.5(12)$ & $1.6 \pm 0.5(18)^{*}$ & $3.8 \pm 0.9(12)$ \\
\hline
\end{tabular}

Number of observations shown in parentheses. Dosage regimen of $2.0 \mathrm{mg} / \mathrm{kg}$ began with $1 \mathrm{dose}$ of $3.0 \mathrm{mg} / \mathrm{kg}$.

*Significantly different from preterm results $(P<0.005)$.

hours. The preterm infants varied in gestation from 24 to 36 (mean 31) weeks, and in birthweight from 0.58 to 2.42 (mean 1.62 ) $\mathrm{kg}$ and the term infants varied in gestation from 37 to 40 (mean 39) weeks, and in birthweight from 1.97 to 4.96 (mean 3.37 ) $\mathrm{kg}$. Age at the start of treatment was less than 7 days in each. The results of the peak, trough, and peaktrough plasma netilmicin levels are shown in Table 1. Analysis of the results showed the mean trough level of the preterm infants to be significantly greater than that of the term infants. The mean peak level of the preterm infants was also significantly greater than that of term infants but this was the consequence of the higher preterm trough level since the mean peak-trough difference in the two groups was almost identical.

In only 9 of 36 determinations was the preterm trough level less than $3 \mu \mathrm{g} / \mathrm{ml}$ and the range of trough levels was from $2 \cdot 1$ to $5.4 \mu \mathrm{g} / \mathrm{ml}$. Concern about the possible toxicity of high trough levels led to a modified regimen in a group of 9 preterm infants (gestation 28-34 weeks, birthweight 0.94 $2.31 \mathrm{~kg}$ ) who were given $2.5 \mathrm{mg}$ netilmicin $/ \mathrm{kg}$ every 12 hours and in whom 13 determinations of peak and trough levels were made. The mean peak and trough levels in this group were lower than those in infants given $3.0 \mathrm{mg} / \mathrm{kg}$ but the peak-trough difference was similar (Table 1). However in 7 out of 13 determinations the trough level was above $3 \mu \mathrm{g} / \mathrm{ml}$. This was deemed to be unacceptable and led to the third dosage regimen being evaluated: 3 $\mathrm{mg}$ netilmicin $/ \mathrm{kg}$ immediately followed by $2 \mathrm{mg} / \mathrm{kg}$ every 12 hours. Measurements were made on 11 preterm infants (gestational age 27-35 weeks, birthweight $0.98-2.02 \mathrm{~kg}$ ) and 13 term infants (gestational age 37-41 weeks, birthweight 2.70-4.62 $\mathrm{kg}$ ). All the trough values in the term group were below $3 \mu \mathrm{g} / \mathrm{ml}$ and only 2 of 25 preterm trough levels were above $3 \mu \mathrm{g} / \mathrm{ml}$. On this dosage the mean peak-trough difference was similar in preterm and term infants but proportionately lower than for infants given $3.0 \mathrm{mg} / \mathrm{kg}$. The mean peak concentrations were consequently lower too (Table 1 ).

Twelve preterm infants (gestational age 26-35 weeks, birthweight $1 \cdot 00-2 \cdot 16 \mathrm{~kg}$ ) and 4 term
Table 2 Mean $\pm S D$ plasma gentamicin levels $(\mu \mathrm{g} / \mathrm{ml})$ in preterm and term infants ages less than 7 days given $3 \mathrm{mg} / \mathrm{kg}$ followed by $2 \mathrm{mg} / \mathrm{kg}$ every 12 hours

\begin{tabular}{llll}
\hline & Peak & Trough & Peak-trough \\
\hline Preterm & $5 \cdot 8 \pm 1 \cdot 3(38)$ & $2 \cdot 2 \pm 1 \cdot 2(38)$ & $3 \cdot 6 \pm 0 \cdot 9(38)$ \\
Term & $5 \cdot 5 \pm 1 \cdot 8$ (7) & $1 \cdot 7 \pm 1 \cdot 2(7)$ & $3 \cdot 8 \pm 1 \cdot 4(7)$ \\
\hline
\end{tabular}

Number of observations in parentheses.

infants (gestational age 37-40 weeks, birthweight $3 \cdot 2-4 \cdot 1 \mathrm{~kg}$ ) given gentamicin in the dosage regimen $3.0 \mathrm{mg} / \mathrm{kg}$ immediately followed by $2.0 \mathrm{mg} / \mathrm{kg}$ every 12 hours had very similar peak, trough, and peaktrough results to those infants receiving netilmicin at this dosage (Tables 1 and 2).

Observations were also made in 7 preterm infants requiring netilmicin, aged 4-7 weeks. Because of a presumed increase in glomerular function the infants were given $3 \mathrm{mg} / \mathrm{kg}$ every 8 hours. The mean \pm SD trough level was $2.9 \pm 0.7 \mu \mathrm{g} / \mathrm{ml}$ $(\mathrm{n}=13)$, peak: $7 \cdot 7 \pm 1 \cdot 2(\mathrm{n}=13)$, peak-trough $4.7 \pm 1 \cdot 1(n=13)$. Although 7 of the 14 trough determinations were over $3 \mu \mathrm{g} / \mathrm{ml}$ the highest was $3.5 \mu \mathrm{g} / \mathrm{ml}$ which was not considered excessive.

\section{Discussion}

Earlier studies on the pharmacokinetics of netilmicin in the newborn ${ }^{457}$ had reported safe peak and trough levels using a dosage regimen of $3 \mathrm{mg} / \mathrm{kg}$ every 12 hours for infants younger than 7 days, and every 8 hours for term infants older than 1 week. Prolonged serum half-lives in infants of low birthweight, gestational age, and postnatal age, ${ }^{467}$ and wide ranges of serum levels reported, ${ }^{3-5}$ gave a general indication for additional studies on these 'high-risk' newborn infants in order to define the optimal dosage regimen for therapy without toxicity. The preterm infants in the study had a lower mean birthweight and a lower mean gestational age than in previous reports, and there were differences in methodology. The chosen method of administration was intravenous bolus injection rather than by intramuscular injection or intravenous infusion. The results show that satisfactory 
peak and safe trough plasma levels of netilmicin can be achieved in preterm and term infants younger than 1 week who are given $3 \mathrm{mg} / \mathrm{kg}$ immediately followed by $2 \mathrm{mg} / \mathrm{kg}$ every 12 hours.

Subdivision of the newborn infants into preterm and term infants showed significantly different serum levels so that for the $3 \mathrm{mg} / \mathrm{kg} 12$ hourly regimen the peak levels were satisfactory but trough concentrations exceeded the recommended maximum of $3 \mu \mathrm{g} / \mathrm{ml}$ in 27 of 36 preterm and 5 of 25 term measurements. The high trough values in the term babies varied from 3.2 to $4.4 \mu \mathrm{g} / \mathrm{ml}$ and caused less concern than those in the preterm infants in whom the maximum reading was 5.4 $\mu \mathrm{g} / \mathrm{ml}$. The results were better when the dose was reduced to $2.5 \mathrm{mg} / \mathrm{kg}$ every 12 hours but satisfactory results for both groups were not achieved until the dose was lowered to $2 \mathrm{mg} / \mathrm{kg}$. A loading dose of $3 \mathrm{mg} / \mathrm{kg}$ was used to ensure a satisfactory peak concentration from the start of treatment.10

The distribution of aminoglycosides, in this case netilmicin, is related to birthweight and postnatal age. The volume of distribution of the drug depends on the extracellular fluid space of the patient, ${ }^{11}$ with the result that lower peak and smaller peak-trough differences are seen in low birthweight infants who have a larger fractional extracellular volume. The differences in trough-peak rise between preterm and term infants were not significant, but proportional to the size of the dose given.

The pharmacological differences observed clearly between preterm and term newborn infants are associated with maturation of renal function. ${ }^{11}$ In the first week of life renal elimination of aminoglycosides is sufficiently low to require a dosage interval of 12 hours but preterm or term infants over age 1 week tolerated a dosage regimen of $3 \mathrm{mg} / \mathrm{kg}$ every 8 hours with satisfactory blood levels, the highest trough observed being $3.5 \mu \mathrm{g} / \mathrm{ml}$. These results are ascribed to postnatal maturation of renal function.

Term newborn infants less than age 7 days can be given $2,2.5$, or $3 \mathrm{mg} / \mathrm{kg} 12$ hourly safely, and preterm infants tolerate $2 \mathrm{mg} / \mathrm{kg} 12$ hourly. The lower dosage was required in the latter group for adequate clearance of netilmicin because of an even more immature renal function related to low birthweight and gestational age. Finally we chose $3 \mathrm{mg} / \mathrm{kg}$ immediately followed by $2 \mathrm{mg} / \mathrm{kg} 12$ hourly for both groups because this was an adequate regimen, simple to implement by the resident medical staff.

It was not surprising to find that plasma levels of netilmicin were similar to those of gentamicin at this dosage in view of the structural similarity of the two drugs and the results from other comparative kinetic studies. ${ }^{712}$ In agreement with these investigators the gentamicin blood levels were more variable than the netilmicin blood levels. Nevertheless unless netilmicin is proved to have a remarkably low toxicity in neonates, its dependence on renal elimination still applies and treatment requires individual blood level monitoring with dosage adjustment. This type of monitoring has shown that satisfactory peak and trough plasma levels of netilmicin are obtained in newborn infants on dosage regimens varying between 4 and $9 \mathrm{mg} / \mathrm{kg}$ a day; the daily dosage used is defined by the gestational and postnatal age of the infant. The decision to give the drug 2 or 3 times a day depends on the judgement of the clinician and bacteriologist on whether it is more important to have a high peak level or more frequent peaks during treatment.

We thank Mrs E F Foster and the nursing and medical staff of the Regional Intensive Care Unit, Jessop Hospital for Women, Sheffield, for help in sample collection. The National Medical Research Fund and Kirby-Warrick Pharmaceuticals Limited provided financial support.

\section{References}

1 Bowman RL, Silverblatt FJ, Kaloyanides GJ. Comparison of the nephrotoxicity of netilmicin and gentamicin in rats. Antimicrob Agents Chemother $1977 ; 12: 474-8$.

2 Miller GH, Arcieri G, Weinstein MJ, Waitz JA. Biological activity of netilmicin, a broad-spectrum semisynthetic aminoglycoside antibiotic. Antimicrob Agents Chemother 1976; 10: 827-36.

3 Brooke I. Tolerance and efficacy of netilmicin in pediatric patients with gram-negative pneumonia. Chemotherapy $1980 ; 26$ : 452-60.

4 Henriksson P, Svenningsen N, Juhlin I, Haeger K. Netilmicin in moderate to severe infections in neonates and infants: a study of efficacy, tolerance, and pharmacokinetics. Curr Ther Res 1978; 24: 108-22.

5 Peitersen B, Horlyk $\mathrm{H}$, Nielson $\mathrm{M}$, et al. Netilmicin: efficacy and tolerance in the treatment of systemic infections in neonates. Scand J Infect Dis 1980; Supplement 23, 151-4.

- Chindasilpa V, Schauf V, Hamilton LR, Riff LJ. Netilmicin use in pediatric patients. Dev Pharmacol Ther 1980; 1: 238-53.

7 Siegel JD, McCracken GH, Jr, Thomas ML, Threlkeld N. Pharmacokinetic properties of netilmicin in newborn infants. Antimicrob Agents Chemother 1979; 15: 246-53.

8 Trujillio H, Manotas R, Loaiza J. Safety and efficacy of netilmicin in neonates with serious systemic infections. $J$ Int Med Res 1981 ; 9: 52-7.

9 Fu KP, Neu HC. In vitro study of netilmicin compared with other aminoglycosides. Antimicrob Agents Chemother 1976; 10: 525-34.

10 Milner RDG, Ross J, Froud DJR, Davis JA. Clinical pharmacology of gentamicin in the newborn infant. Arch Dis Child 1972; 47: 927-32.

11 Riff L, Schauf V. Use of aminoglycosides in the neonate. Semin Perinatol 1982; 6: 155-65.

12 Riff LJ, Moreschi G. Netilmicin and gentamicin: comparative pharmacology in humans. Antimicrob Agents Chemother 1977; 11 : 609-14.

Correspondence to Professor R D G Milner, Department of Paediatrics, Children's Hospital, Sheffield S10 2TH.

Received 24 January 1983 